\title{
EFFECT OF SLIVER NANOPARTICLES WITH COTULA CINERIA EXTRACT ON GROWING RABBITS PERFORMANCE, DIGESTIBILITY AND CARCASS QUALITY.
}

\author{
M.S.M. Abousekken'; Y.A. Abd El Hady²; N.M.ElAbd1 and Z.A.Anter²
}

\section{$\underline{\text { ABSTRACT }}$}

$\mathrm{T}$ he current study was carried out to investigate the effect of sliver nanoparticles (40 $50 \mathrm{~nm} \mathrm{|)} \mathrm{with} \mathrm{Cotula} \mathrm{cineria} \mathrm{extract} \mathrm{(CCE)} \mathrm{on} \mathrm{growing} \mathrm{Rabbits} \mathrm{Performance,} \mathrm{Digestibility} \mathrm{and}$ Carcass quality. Total of 24 growing NewZealand white (NZW) rabbits of both sexes at 5 weeks of age (with average weight $857 \pm 80.87 \mathrm{~g}$ ) were at random assigned to four equal groups, each group consists of 6 rabbits, in three replicates. . Rabbits in all experimental groups were fed the same basal diet. Rabbits in the $1^{\text {st }}$ group (control) were fed the basal diet without treatment, while in the $2^{\text {nd }}$ group were fed the basal diet treated with Extract at a dose of $250 \mathrm{mg} / \mathrm{rabbit} / \mathrm{day}$, in the $3^{\text {rd }}$ group were fed the basal diet treated with sliver nanoparticles at a dose of $10 \mathrm{mg} / \mathrm{kg}$ body weight $(\mathrm{BW})$ per day, the $4^{\text {th }}$ group were fed the basal diet treated with sliver nanoparticles with Cotula cineria extract at a dose of $10 \mathrm{mg} / \mathrm{kg} /$ day from sliver nanoparticles $+125 \mathrm{mg} / \mathrm{rabbit}$ /day from extract. Live body weight (LBW), digestibility coefficients (DC) and carcass traits were determined for up to 13 weeks of age. Results showed that Live body weight had significant effect $(\mathrm{p}<0.05)$ in $3^{\text {rd }}, 5^{\text {th }}$ week and no significant effect in all experimental weeks. Live body weight gain had no significant effect $(p<0.05)$ in all experimental weeks and TG and the best values were in group (CCE). Feed intake weekly had significant effect $(p<0.05)$ in all weeks of experiment and TFI, the best values were in group (CCE) (1291.7) in $3^{\text {rd }}$ week. No significant differences $(p<0.05)$ were observed in FCR within experimental weeks except FCR5 the best value was in group (CCE) ( 2.25) in FCR1.About Carcass characteristics there was significant effect on Cecum length, Abdominal fat but differences in Live Body Weight, Cecum weight and Dressing \%were not significant.

Apparent digestibility of OM, CP and NFE were significantly $(p<0.05)$ and the best values were in group (SNPs) (74.66,73.85,80,03 respectively)may be due to the effect of silver Nano particles on intestinal microbial populations and improve the health and immunological status of the birds This can provide the birds with an opportunity to expend less metabolic effort for immunological control purposes and to use surplus nutrients for other physiological and productive purposes Ferket P; (2011), Furthermore, it is speculated that, as a carrier of available oxygen, silver nanoparticles could also be a potent modifier of metabolism. Silver nanoparticles and it is possible that the oxygen that accumulates in the octahedral holes of silver nanoparticles may increase anabolic activity and subsequently stimulate growth and development.

It is recommended to use sliver nanoparticles on growing rabbit diets, to improve performance, digestibility and carcass characteristics, Because of their unique biological properties and strong antimicrobial activity, silver nanoparticles have received considerable attention and been used widely in an increasing number of consumer and medical products. 


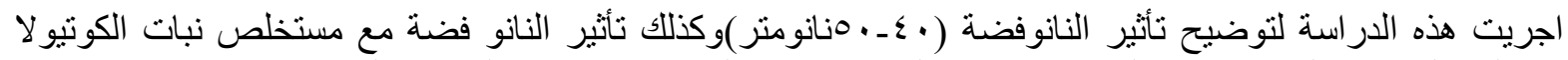

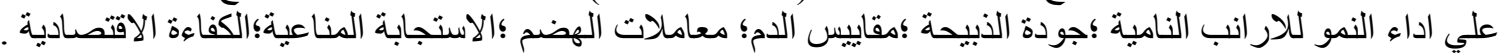

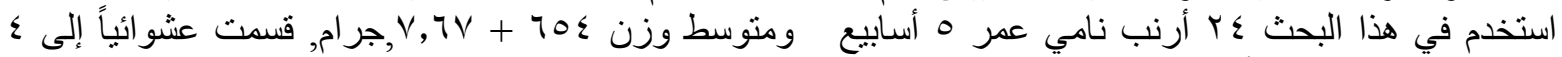

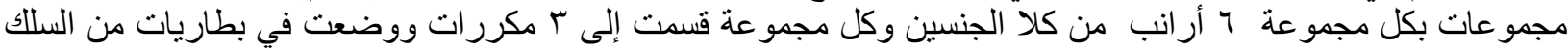

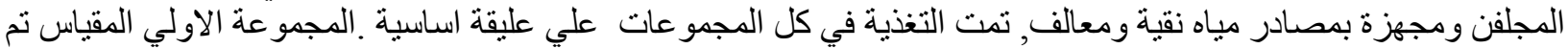

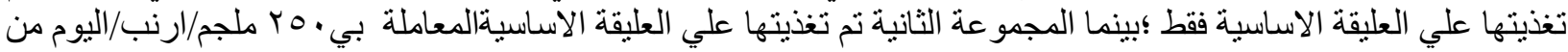

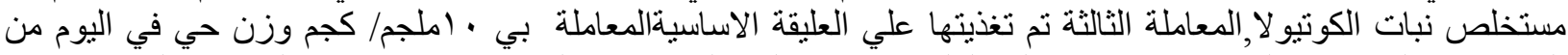

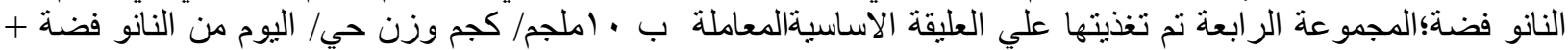

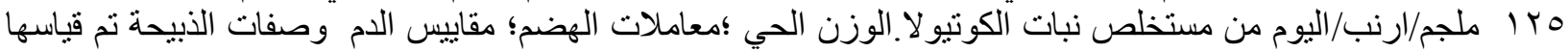

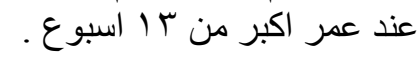

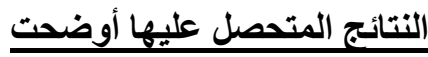

وجود تحسن معنوي فيق أوضي وزن الجسم الحي في الاسبوع الثالث والخامس ولا يوجد تحسن معنوي في باقي اسابيع التجربة. لا يوجد تحسن معنوي بالنسبة للزيادة في الوزن في كل اسابيع التجربة وكذللك الزيادة الكلية في الوزن و أفضل زيادة

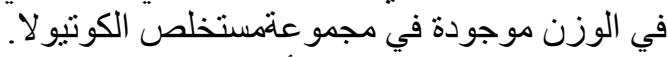

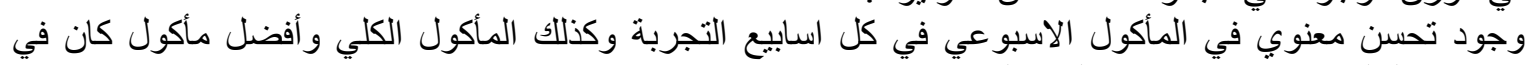

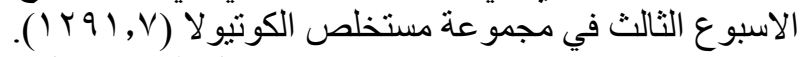

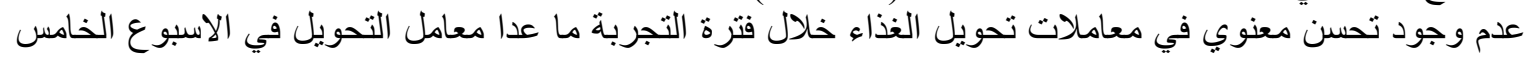

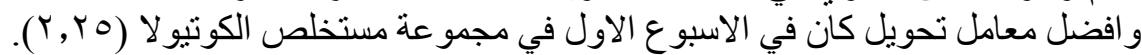

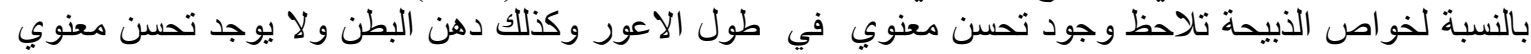

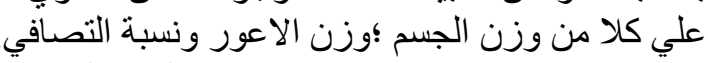

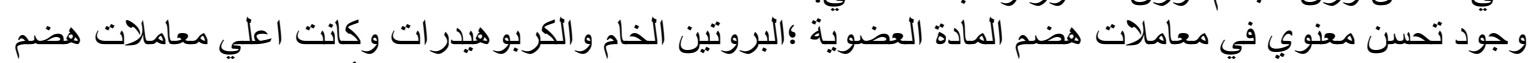

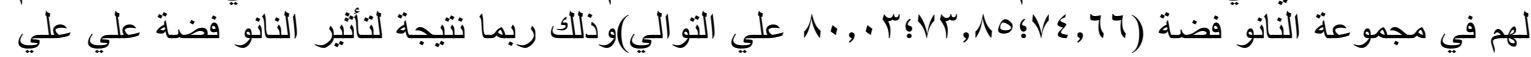

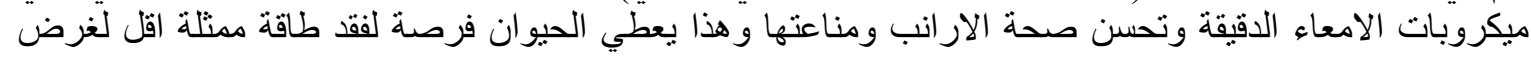

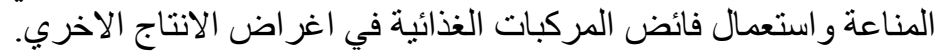

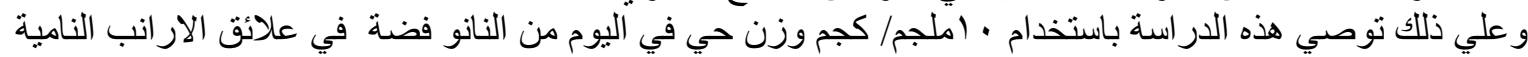
لتحسين اداء النمو ؛معاملات الهضم وجودة بالـة الذبيحة .

\section{INTRODUCTION}

In the last two decades, several types of additives have been proposed in pig production as alternatives to the use of antibiotics as growth promoters, such as organic acids, oligosaccharides, plant extracts or probiotics (Cowan, 1999; Naughton et al., 2001; Gardiner et al., 2004; Franco et al., 2005). However, their effect in preventing digestive disorders at weaning and promoting higher productive performances is variable and in most cases below the magnitude previously reached with the use of antibiotics.

Due to the outbreak of the infectious diseases caused by different pathogenic bacteria and the development of antibiotic resistance the pharmaceutical companies and the researchers are searching for new antibacterial agents. Nanoscale materials have emerged up as novel antimicrobial agents owing to their high surface area to volume ratio and the unique chemical and physical properties (Morones et al., 2005; Kim et al., 2007). Nanotechnology is emerging as a rapidly growing field with its application in Science and Technology for the purpose of manufacturing new materials at the nanoscale level (Albrecht et al., 2006). The word "nano" is used to indicate one billionth of a meter or 10-9. The term Nanotechnology was coined by Professor Norio Taniguchi of Tokyo Science University in the year 1974 to describe precision manufacturing of materials at the nanometer level (Taniguchi, 1974). The concept of Nanotechnology was given by physicist Professor Richard P. Feynman in his lecture There's plenty of room at the Bottom(Feynman, 1959). Nanoparticles are clusters of atoms in the size 
range of 1-100 nm. "Nano" is a Greek word synonymous to dwarf meaning extremely small. The use of nanoparticles is gaining impetus in the present century as they posses defined chemical, optical and mechanical properties. The metallic nanoparticles are most promising as they show good antibacterial properties due to their large surface area to volume ratio, which is coming up as the current interest in the researchers due to the growing microbial resistance against metal ions, antibiotics and the development of resistant strains (Gong et al., 2007). Different types of nanomaterials like copper, zinc, titanium (Retchkiman-Schabes et al., 2006), magnesium, gold (Gu et al., 2003), alginate (Ahmad et al., 2005) and silver have come up but silver nanoparticles have proved to be most effective as it has good antimicrobial efficacy against bacteria, viruses and other eukaryotic micro-organisms (Gong et al., 2007). Silver nanoparticles used as drug disinfectant have some risks as the exposure to silver can cause agyrosis and argyria also; it is toxic to mammalian cells (Gong et al., 2007).

Silver is toxic to microorganisms by poisoning respiratory enzymes and components of the microbial electron transport system, and it also binds to bacterial surface, altering the membrane function(Percival et al., 2005), and to DNA bases, thus inhibiting replication (Wright et al., 1994).

Because of their unique biological properties and strong antimicrobial activity, silver nanoparticles have received considerable attention and are being used widely in an increasing number of consumer and medicinal products( Kim et al.,2007; Varner et al.,2010). In the current study, we investigated the effect of sliver nanoparticles with Cotula Cineria extract on growing Rabbits Performance, Digestibility and Carcass quality.

\section{MATERIALS AND METHODS}

The present study was carried out at Rabbit Research Station belonging to Environmental Studies and Research Institute, University of Sadat City, University of Sadat City during the period from September to November, 2017.

This study carried out to investigate the effect of adding three feed additives (Extract, Nano silver, Nano silver + extract,) to the diet of rabbits every day plus Control on performance of New Zealand White rabbits during the growing period. Also, to investigate the effect of these additives on the digestibility coefficient of nutrients, carcass traits, immune response, blood parameters, and economic efficiency.

\section{PREPARATION OF METHANOL EXTRACT}

The whole plant was collected from Sadat university farm, carefully, were then washed with distilled water. The whole plant was air dried in the shade at room temperature $\left(27-29^{\circ} \mathrm{c}\right)$ for 10-15 days and then ground into fine powder using an electric blender for $2 \mathrm{~min}$. The dried power $(100 \mathrm{~g})$ was soaked into $(1 \mathrm{~L})$ of methanol for $48 \mathrm{~h}$ at room temperature. To avoid light exposure, the flask was left in the dark. The mixtures were first filtered through double layered of whatman No.1 filter paper. The extract was concentrated using a rotary evaporator at $60^{\circ} \mathrm{c}$ and afterward dried in oven at $50^{\circ} \mathrm{c}$ for $48 \mathrm{~h}$ (E.A. Elsherbiny et al(.2016).

The hydrocolloid of Nano silver and Nano silica were obtained from NIS-National Institute for Standards-EGYPT. Nano zinc oxide was obtained from National Laser Institute

\section{ANIMALS:}

Twenty-four growing New Zealand white (NZW) rabbits of both sexes at 5 weeks of age (with average weight $654 \pm 7.67 \mathrm{~g}$ ) were at random assigned to four equal groups, each group consists of 6 rabbits, in three replicates. 


\section{EXPERIMENTAL DIETS:}

Three feed additives were added to the commercial rabbits diet Daly expect control group $\left(T_{1}\right)$ which fed diet without any feed additives.

Extract Group ( $\left.\mathbf{T}_{2}\right)$ fed $250 \mathrm{mg} / \mathrm{rabbit} /$ day from extract dissolved in $40 \mathrm{ml}$ distilled water after that distributed to the basal diet from day 1 to 60 of the experiment on growing New Zealand white (NZW) rabbits .

Nano silver Group ( $\left.\mathbf{T}_{3}\right)$. fed 10mg / kg/day from Nano silver dissolved in $40 \mathrm{ml}$ distilled water after that distributed to the basal diet from day 1 to 60 of the experiment on growing New Zealand white (NZW) rabbits.

Nano silver + extract Group.(T) $\left.\mathbf{T}_{4}\right)$ fed ( $10 \mathrm{mg} / \mathrm{kg} / \mathrm{day}$ from Nano silver + 125mg/rabbit /day from extract) mixed them and dissolved in $40 \mathrm{ml}$ distilled water after that distributed to the basal diet from day 1 to 60 of the experiment on growing New Zealand white (NZW) rabbits .

water after that distributed to the basal diet from day 1 to 60 of the experiment on growing New Zealand white (NZW) rabbits .

Group (control). Without any feed additives to the basal diets.

All groups were kept under the same managerial and hygienic conditions. The experimental rabbits were housed in individual cage batteries provided with feeders and drinkers. Diets were offered ad libitum in pelleted form and fresh water was available all times from automatic drinkers with nipples. All rabbits were vaccinated against the common diseases. All experimental procedures were carried out according to the Local Experimental Animal Care Committee and approved by the ethics of the institutional committee of Research Institute, University of Sadat City.

\section{EXPERIMENTAL DESIGN}

Rabbits were divided randomly into four experimental groups of six rabbits. Rabbits were housed individually in double flat galvanized wire batteries $(40 \times 30 \times 25 \mathrm{~cm})$ with fodder and automatic nipple drinkers. The batteries were arranged in rows in a windowed house naturally ventilated. Feed and eater were available ad libitum. Experiments lasted for 8 weeks. During the experimental period (8weeks), live body weight (LBW) and feed intake (FI) were weekly recorded. Average weight gain (BWG)and feed conversion ratio (FCR) were calculated.

At the end of the experimental period, digestion trials were carried out by using 4 male rabbits (at 13 weeks of age) from each group to determine the digestible coefficients of the experimental diets. The total excreted feces during the collection period were pooled, well mixed, weighed and sampled for analysis.

Representative male and female rabbits (at 15weeks of age) from each treatment were randomly taken for slaughter test and carcass weights were calculated as a percentage of live body weight. Proximate analysis of diets, dried feces and meat were carried out on representative samples according to A.O.A.C(1984).

Data were subjected to analysis of variance using the general linear model (GLM) procedure of SAS (2004). Main effects of differences obtained upon statistical analysis were compared using Duncan's multiple range test (Duncan, 1955), to detect significant differences among means. 

University of Sadat city,

Environmental Studies and Research

$5^{\text {Th }}$ International Conference

"New Horizons Towards Comprehensive Development"

Hurghada, Egypt 1-4 April 2019

Journal of Environmental Studies and Researches (2019), 9(A)80 - 91

Table 1 : Growth performance of rabbits as affected by Ag Nanoparticles with Cotula cineriea extract (means \pm S.E).

\begin{tabular}{|c|c|c|c|c|c|}
\hline \multirow{2}{*}{ Items } & \multicolumn{4}{|c|}{ Treatments } & \multirow[t]{2}{*}{ Sign } \\
\hline & Control (T 1) & $\mathrm{T} 2$ & T3 & T4 & \\
\hline Initial live body weight (g)LBW (g): & $80.9 \wedge \vee r, \mu_{ \pm}$ & $80.99 \vee \vee, r_{ \pm}$ & $80.9 \vee q \cdot, r_{ \pm}$ & $80.99 \cdot \wedge, \cdot \pm$ & N.S \\
\hline LBWK1(g) & $77.794 \varepsilon, r \pm$ & $73.71 \cdot 09, \cdot \pm$ & $73.7 \wedge \uparrow \vee, r_{ \pm}$ & $73.71 \cdot 1 \leqslant, r_{ \pm}$ & N.S \\
\hline LBWK3(g) & $1326.7^{b} \pm 86.5$ & $85.1 \pm 1605.0^{2}$ & $85.1 \pm 1250.7^{b}$ & $85.1 \pm 1495.0^{2 b}$ & $*$ \\
\hline LBWK5(g) & $1699.0^{b} \pm 90.0$ & $90.0 \pm 2013.7^{2}$ & $90.0 \pm 1683.7^{b}$ & $90.0 \pm 1909.3^{2 b}$ & * \\
\hline LBWK7(g) & $\curlyvee \cdot r \checkmark, \vee \pm 106.7$ & 106.7rrro,· & $106.7199 \bullet, \cdot \pm$ & $106.7 r \mid 0 \leqslant, r \pm$ & N.S \\
\hline$\frac{\text { IBWG }(g):}{\text { IBWG1 }}$ & $35.7^{\wedge} \varepsilon, \vee_{ \pm}$ & $35.7 ๕ 4, \cdot \pm$ & $35.7 r^{\top}, v_{ \pm}$ & $35.71 \cdot 7, r_{ \pm}$ & N.S \\
\hline LBWG3 & $50.5 \curlyvee \backslash \vee, \cdot \pm$ & $\left.50.5^{\mu}\right) \mu, \cdot \pm$ & $50.5 \curlyvee \bullet 1, \cdot \pm$ & $50.5 \curlyvee \wedge \cdot, \vee_{ \pm}$ & N.S \\
\hline LBWG5 & $30.7117, \cdot \pm$ & $30.7 \backslash \leqslant \varepsilon, r_{ \pm}$ & 30.7 $\vee \vee \vee, r_{ \pm}$ & $30.719 \wedge, r_{ \pm}$ & N.S \\
\hline LBWG7 & $31.4 \backslash \leqslant \neg, r_{ \pm}$ & $31.4 \backslash 19, \cdot \pm$ & $31.4 \backslash \bullet r, r_{ \pm}$ & $31.4 \backslash \wedge \vee, \diamond_{ \pm}$ & N.S \\
\hline $\begin{array}{l}\text { TG } \\
\text { FI(g): }\end{array}$ & $108.9 \backslash$ \更, & $108.91 r \varepsilon \vee, v_{ \pm}$ & $108.9 \mid r \cdot \varepsilon, V_{ \pm}$ & $108.9 \mid r \leq \checkmark, r \pm$ & N.S \\
\hline FI1(g) & $308.3^{b}$ & $350.0^{2}$ & $250.0^{\mathrm{C}}$ & $350.0^{2}$ & * \\
\hline FI3 & $1015.7^{\mathrm{f}}$ & $1291.7^{2}$ & $1084.3^{\mathrm{c}}$ & $1162.0^{\mathrm{b}}$ & * \\
\hline FI5 & $v_{l} \cdot, \mathrm{rf}_{\mathrm{f}}$ & $\Delta \curlyvee q, r_{h}$ & $\wedge \leq 1, r b$ & $\bullet \vee \varepsilon, r g$ & * \\
\hline FI7 & $1 . \leq 4,0 b$ & $1 \cdot \wedge \varepsilon, v a$ & $q r r, \wedge h$ & $1.1 \mathrm{r}, \mathrm{rc}$ & * \\
\hline TFI & $\varepsilon \varepsilon r \varepsilon, r g$ & $0 . r r, \uparrow a$ & $\varepsilon \leqslant \uparrow \theta, r \mathrm{f}$ & $\{790,9 c$ & * \\
\hline$\frac{\text { FCR (g feed/g gain): }}{\text { FCR1 (g feed/g gain) }}$ & $3.23 \pm 1.84$ & $2.25 \pm 2.38$ & $2.36 \pm 2.38$ & $.86 \pm 1.84$ & N.S \\
\hline FCR3 (g feed/g gain) & $7.95 \pm 1.8$. & $4.30 \pm 1.80$ & $5.74 \pm 1.80$ & $5.55 \pm 1.80$ & N.S \\
\hline FCR5 (g feed/g gain) & $7.19^{a b} \pm 1.43$ & $4.14^{b} \pm 1.43$ & $5.60^{a b} \pm 1.43$ & $3.68^{b} \pm 1.43$ & $*$ \\
\hline FCR7 (g feed/g gain) & $9.46 \pm 3.28$ & $11.65 \pm 3.28$ & $9.51 \pm 3.28$ & $7.03 \pm 3.28$ & N.S \\
\hline TFC(g feed/g gain) & $3.87 \pm 0.36$ & $3.92 \pm 0.36$ & $3.89 \pm 0.36$ & $3.94 \pm 0.36$ & N.S \\
\hline
\end{tabular}

Journal of Environmental Studies and Researches (2019), 9(A) (Special Issue) Issued by Environmental Studies and Researches Institute (ESRI), University of Sadat City 
University of Sadat city,

Environmental Studies and Research

$5^{\text {Th }}$ International Conference

"New Horizons Towards Comprehensive Development"

Hurghada, Egypt 1-4 April 2019

\begin{tabular}{|c|c|c|c|c|c|}
\hline \multirow{2}{*}{ Items } & \multicolumn{4}{|c|}{ Treatments } & \multirow{2}{*}{ Sign } \\
\hline & Control (T1) & T2 & T3 & T4 & \\
\hline Live Body Weight(g) & $19 \wedge \varepsilon, \cdot \pm 119, V$ & YrYA, $\pm 119, \vee$ & $1 \wedge \neg 1, r_{ \pm} \mid 19, v$ & $Y \ldots \varepsilon, \curlyvee \pm 119, V$ & N.S \\
\hline Cecum weight (g) & $q, r \pm 1, q$ & $1 r, r \pm 1, q$ & $I Y, \cdot \pm r, r$ & $1 \varepsilon, \cdot \pm Y, r$ & N.S \\
\hline Cecum length $(\mathrm{cm})$ & $\pm \cdot, \vee 11.7^{\text {abc }}$ & $\pm \cdot, \vee 11.7^{a b c}$ & $\pm \cdot, \vee 10.2^{c}$ & $\pm \cdot, \vee 11.7^{\mathrm{abc}}$ & $*$ \\
\hline Abdominal fat $\%$ & $\pm \vee, \Upsilon 15.3^{\mathrm{ab}}$ & $\pm \vee, \nearrow \quad 37.3^{\mathrm{a}}$ & $\pm \vee, 74.0^{b}$ & $\pm \vee, \Upsilon 22.7^{\mathrm{ab}}$ & $*$ \\
\hline Dressing \% & $V r, V \pm r, \theta$ & $V \varepsilon, \cdot \pm Y, 0$ & $V r, \varepsilon \pm r, 0$ & $V \varepsilon, \cdot \pm r, 0$ & N.S \\
\hline
\end{tabular}

Table . 2 Carcass characteristies of experimental rabbits as affected by Ag Nanoparticles with Cotula cineriea extract.

a, $b, c \ldots . . . e$ values within a row with different superscripts significantly different $(p<0.05)$.

$*=\mathrm{p}<0.05 \mathrm{NS}=$ not significant $\mathrm{SE}=$ standard error

T1 (Control), T2 = Extract ,T3 = Ag Nanoparticles , T4 = Ag Nanoparticles with

Table.6 Digestibility Coefficients Of experimental rabbits as affected by Ag Nanoparticles with Cotula cineriea extract.

\begin{tabular}{|l|c|c|c|c|c|}
\hline \multirow{2}{*}{ Items } & \multicolumn{5}{c|}{ For :\% Digestibility Coefficients } \\
\cline { 2 - 6 } & OM & CP & CF & EE & NFE \\
\hline $\begin{array}{l}\text { Control } \\
\text { (T1) }\end{array}$ & $\mathbf{6 4 . 8 6}^{\mathrm{ab}} \pm 3.53$ & $66.86^{\mathrm{b}} \pm 3.02$ & $31.39 \pm 7.52$ & $82.00 \pm 9.08$ & $\mathbf{7 2 . 6 5}^{\mathrm{a}} \pm 3.14$ \\
\hline T2 & $\mathbf{6 6 . 2 2}^{\mathrm{ab}} \pm 3.53$ & $75.10^{\mathrm{b}} \pm 3.02$ & $\mathbf{2 3 . 3 6} \pm 7.52$ & $\mathbf{5 6 . 1 5} \pm 9.08$ & $\mathbf{7 3 . 4 5}^{\mathrm{a}} \pm 3.14$ \\
\hline T3 & $74.66^{\mathrm{a}} \pm 3.53$ & $73.85^{\mathrm{b}} \pm 3.02$ & $39.61 \pm 7.52$ & $75.94 \pm 9.08$ & $\mathbf{8 0 . 0 3}^{\mathrm{a}} \pm 3.14$ \\
\hline T4 & $\mathbf{6 4 . 9 9}^{\mathrm{ab}} \pm 3.53$ & $72.28^{\mathrm{b}} \pm 3.02$ & $19.18 \pm 7.52$ & $82.09 \pm 9.08$ & $\mathbf{7 2 . 5 3}^{\mathrm{a}} \pm 3.14$ \\
\hline Sign & $*$ & $*$ & N.S & N.S & $*$ \\
\hline
\end{tabular}

$\mathbf{a}, \mathbf{b}, \mathbf{c}$.......e values within a column with different superscripts significantly different $(\mathrm{p}<0.05)$. $*=\mathrm{p}<0.05 \mathrm{NS}=$ not significant $\mathrm{SE}=$ standard error

T1 (Control), T2 = Extract ,T3 = Ag Nanoparticles, T4 = Ag Nanoparticles with 


\section{RESULTS AND DISCUSSION \\ GROWTH PERFORMANCE:- LIVE BODY WEIGHT}

Live body weight of experimental rabbits as affected by Ag Nanoparticles with Cotula cineriea extract are presented in Table (1) The results showed that Initial live body weight (g) ranged between 977.3 to 790.3 in group extract and group Ag Nanoparticles respectively but these differences were not significant. Also LBWK1 $(\mathrm{g})$ had no significant effect, values ranged between 1059.0 to 867.3. While LBWK3(g), LBWK5(g) had significantly $(\mathrm{p}<0.05)$, the highest value 1605.0 , 2013.7 respectively in group Cotula Cineriea extract but the lowest value 1250.7, 1683.7 respectively in group Ag Nanoparticles Fondevila ;2009) indicated that low doses of metallic silver nanoparticles given as dietary additive could improve intake and growth of weaned piglets. The effect of silver could be mediated through its antimicrobial properties, either by acting against certain bacterial groups or just reducing the microbial load of the small intestine, antimicrobial activity of silver is manifested by blocking the electron transport system, altering the function of the bacterial membrane and inhibiting the DNA replication (Wright et al., 1994; Percival et al., 2005). Although these effects have been demonstrated experimentally against E. coli (Zhao and Stevens, 1998; Sondi and Salopek-Sondi, 2004).. LBWK7(g) had no significant effect, values ranged between 2325.0 to 1995.0 in group Cotula Cineriea extract, group Ag Nanoparticles respectively ( Demir et al., 2008; Kirkpinar et al., 2011; Brenes and Roura, 2010; Zeng et al., 2015) showed that essential oils or their components had significantly negative effect on Body weight. On the other hand (Al-Kassie, 2010; Zeng et al., 2015; Khattak et al., 2014; Saleh et al., 2014; Hong et al., 2012; Aguilar et al., 2014; Alali et al., 2013; Roofchaee et al., 2011) showed that essential oils or their components had significantly positive effect on Body weight. This result agree with Ognik et al 2016; Pineda,et al 2012; Ahmadi et al ;2013; Ahmadi and Rahimi ;2011;) when found that Nano silver had significantly negative effect on Body weight

\section{LIVE BODY WEIGHT GAIN}

No significant effect $(\mathrm{p}<0.05)$ was found in IBWG1, LBWG3, LBWG5, LBWG7 and TG Table (1). Group Ag Nanoparticles with Cotula cineriea extract have the highest values of Live body weight gain in all weeks except in LBWG3 against that in group Cotula cineriea extract which have the lowest values of Live body weight gain in all weeks except in LBWG3 and TG(Brenes and Roura, 2010; Zeng et al., 2015).

\section{FEED INTAKE}

Feed intake weekly of experimental rabbits as affected by Ag Nanoparticles with Cotula cineriea extract is found in Table (1), which indicated that FI1(g), FI3, FI5, FI7, TFI had significant differences $(\mathrm{p}<0.05)$ ( Saleh et al., 2014; Zeng et al., 2015). The highest values, lowest values every week and TFI were always in group Cotula Cineriea extract, group Ag Nanoparticles respectively, and Feed intake in week three was the highest and the lowest feed intake in week five.

\section{FCR (G FEED/G GAIN)}

No significant differences $(p<0.05)$ were found in FCR1, FCR3, FCR7 and TFC Table (1).The best value was in group Cotula cineriea extract(2.25) in FCR1 although the worst was in group Cotula cineriea extract(11.65) in FCR7 (Al-Kassie, 2010; Khattak et al., 2014; Hong et al., 2012; Brenes and Roura, 2010; Alali et al., 2013; Saleh et al., 2014; Roofchaee et al., 2011) on the other hand (Demir et al., 2008; Zeng et al., 2015; Kirkpinar et al., 2011; Mountzouris et al., 2011; Mathlouthi et al., 2012;) Essential oil which found in Cotula Cineriea extract is very 
important in terms of feed conversion and these compounds also boost the production of digestive enzymes essential oils also act against Gram-negative bacteria ( Zengin et al 2013; Alali et al., 2013; Cerisuelo et al., 2014; Nimbarte et al 2014 zengin and Baysal, 2014), essential oils also act strong action against Gram-positive bacteria (Nazzaro et al., 2013; Gopi et al., 2014). FCR5 had significant differences $(\mathrm{p}<0.05)$ among treatments ranged between $3.68,4.14$ in group Ag Nanoparticles with Cotula Cineriea extract and group Cotula cineriea extract respectively, this may be due to its content of essential oil that have active components which have possess

antimicrobial, antifungal and antioxidant activities; and accordingly could improve the bird utilization of dietary nutrients (Radwan 2003; Abou Sekken and Abd El-Hakim 2006 ). In addition, Abdel - Latif et al. (2002) attributed the improvement in growth and feed conversion of chicks fed thyme leaves to the enhancement in thyroid activity and the biological role of such medicinal plant in the metabolic functions and biosynthesis of hormones.

\section{CARCASS CHARACTERISTIES:}

Results of Live Body Weight $(\mathrm{g})$ are presented in (table 2) ranged between 2228.6 to 1861.3 1n group Cotula Cineriea extract and group Ag Nanoparticles respectively, but these differences were not significant Ahmadi and Rahimi . 2011; Pineda,(2012; Ahmadi, F 2012; Ognik et al 2016) showed that Nano silver had significantly negative effect on Body weight, also ( Demir et al., 2008; Kirkpinar et al., 2011; Brenes and Roura, 2010; Zeng et al., 2015) showed that essential oils or their components had significantly negative effect on Body weight. On the other hand (Al-Kassie, 2010; Zeng et al., 2015; Khattak et al., 2014; Saleh et al., 2014; Hong et al., 2012; Aguilar et al., 2014; Alali et al., 2013; Roofchaee et al., 2011) showed that essential oils or their components had significantly positive effect on Body weight.

Cecum weight (g) results recorded differences but these differences were not significant and ranged between 14.0 to 12 in group Ag Nanoparticles with Cotula cineriea extract and group Ag Nanoparticles respectively.

Cecum length (cm) Results indicated that significant effect of (SNPs)Ag Nanoparticles with Cotula cineriea extract $(\mathrm{p}<0.05)$ and the highest value was 11.7 similar in group Cotula cineriea extract Abou Sekken and Abd El-Hakim ( 2006 ) and group Ag Nanoparticles with Cotula cineriea extract while the lowest value 10.2 in group Ag Nano.

The observed differences in length and weight of cecum my be attributed to dietary fiber sources (Ismail,2004).

Results of Abdominal fat $\%$ are presented in (table 2) indicated that significant effect of (SNPs)Ag Nanoparticles with Cotula cineriea extract $(\mathrm{p}<0.05)$ and the highest value 37.3 in group Cotula cineriea extract but the lowest value 4.0 in group Ag Nanoparticles with Cotula cineriea extract. The significant increase of abdominal fat $\%$ may be due to that group Cotula cineriea extract is rich in volatile oils, protein, fat, sugars and vitamins (Ansary, 1975), which had beneficial effect for stimulation and activity of digestive system (Ibrahim, 2005; Ahmadi and Rahimi . 2011).

\section{Dressing \%}

Results of Dressing \% showed that ranged between 74 to $73.4 \%$, in group $\mathrm{Ag}$ Nanoparticles with Cotula Cineriea extract and group Ag Nanoparticles respectively, but these differences were not significant.

Ali et al.,2011; Riyazi, (2015; Tabari et al.,2016;Bonsu et al., 2012;) Essential oils or their components were not significantly $(\mathrm{P}>0.05)$ on Carcass characteristics, on the other hand 
(Sharma et al.,2009; Waskar et al.,2011; Oleforuh et al.,2015;Puvaca et al.,2016) essential oils or their components were not significantly $(\mathrm{P}>0.05)$ on Carcass characteristics

\section{DIGESTIBILITY:}

Effects of Ag Nanoparticles with Cotula cineriea extract on Digestibility Coefficients Of experimental rabbits data are presented in Table (3) The results showed that the apparent digestibility of OM, CP and NFE were significantly $(p<0.05)$. Digestibility of $\mathrm{CF}$ ranged between 39.61 to $19.18 \%$ in groups supplemented Ag Nanoparticles and Ag Nanoparticles with Cotula cineriea extract respectively, but these differences were not significant. Group supplemented Ag Nanoparticles recorded significantly $(\mathrm{p}<0.05)$ the best values of NFE and OM digestion coefficients $(80.03$ and $74.66 \%)$ compared with the other experimental diets but group Cotula cineriea extract recorded significantly $(\mathrm{p}<0.05)$ the best values of $\mathrm{CP}$ digestion coefficients (75.10\%). The diet supplemented Ag Nanoparticles with Cotula cineriea extract recorded significantly $(p<0.05)$ the worst value of NFE digestion coefficient $(72.53 \%)$.

Digestibility of EE ranged between 82.09 to $56.15 \%$ in groups supplemented Ag Nanoparticles with Cotula cineriea extract and group extract respectively ,but these differences were not significant. The significant in CP digestibility on group extract, may be due to the effect of flavonoids and essential oils which have a positive effect on the digestive system also boost the production of digestive enzymes, resulting in better digestion and absorption of nutrients. Essential oils also help to improve protein digestion by increasing the secretion of hydrochloric acid and pepsin (Gopi et al., 2014; . CHRENKOVÁ1.,2012;). on the other hand Abou Sekken and Abd El-Hakim ( 2006 ) found that Digestibility of CP, NFE and OM were not significant. The significant in NFE digestibility on group Ag Nanoparticles, may be due to the effect of silver nano particles on intestinal microbial populations and improve the health and immunological status of the birds This can provide the birds with an opportunity to expend less metabolic effort for immunological control purposes and to use surplus nutrients for other physiological and productive purposes Ferket P. (2011).

\section{REFERENCES}

- A g u i l a r c.a.l., l i m a k.r.s., m a n $n$ o m.c., m a i a j.g.s., f e $r$ a $n$ d e s n e t od.l., t a v a - r e s f.b., r o q u e t.j.l., m e n d o n c a r.a., c a r m o e.s.n. (2014). Rosewood (aniba rosaeodora ducke) oil in broiler chickens diet. Revista brasileira de saúde e produção animal, 15, http:// dx.doi.org/10.1590/s1519-99402014000100014.

- A l - k a s s i e g.a.m. (2010). The role of peppermint (mentha piperita) on performance in broiler diets. Agric. Biol. J. North america, 1: 1009-1013.

- A l a l i w.q., h o f a c r e c.l., $m$ a $t$ h i s g.f., f a $l$ t y $s$ g.. (2013). Effect of essential oil compound on shedding and colonization of salmonella enterica serovar heidelberg in broilers. Poultry sci., 3: 836-841.

- Abd el- latif, s.a.; a.i. Faten and a.m. E. Kiaty (2002) effect of feeding dietary thyme, black cumin, dianthus and fennel on productive and some metabolic responses of growing japanese quail. Egypt. Poult. Sci. ,22 (1): 109.

- Abou sekken m.s. And a.s. Abd el-hakim( 2006 ) effect of dietary cotula cinerea meal levels on performance, digestibility, carcass traits and microbial status of growing rabbits under desert conditions .j.of egypt. Poult.sci.(): 
- Ahmad z, pandey r, sharma s, khuller gk.( 2005) alginate nanoparticles as antituberculosis drug carriers: formulation development, pharmacokinetics and therapeutic potential. Ind $\mathrm{j}$ chest dis allied sci 2005;48:171-6.

- Ahmadi f. (2012): impact of different levels of silver nanoparticles (ag-nps) on performance, oxidative enzymes and blood parameters in broiler chicks. Pakistan veterinary journal, $32,325-328$.

- Ahmadi, f.; khah, m. M.; javid, s.; zarneshan, a.; akradi, l.; salehifar, p(2013.). The effect of dietary silver nanoparticles on performance, immune organs, and lipid serum of broiler chickens during starter period. International journal of biosciences (ijb); 2013. 3(5):95-100. 17 ref.

- Ahmadi, f.; rahimi, f.(2011). The effect of different levels of nano silver on performance and retention of silver in edible tissues of broilers. World applied sciences journal; 2011. 12(1):1-4. 10 ref.

- Albrecht ma, evan cw, raston cl(2006). Green chemistry and the health implications of nanoparticles. Green chem 2006;8:417-32.

- Ali, f. A. F.; omer, h. A. A.; abedo, a. A.; abdel-magid, s. S.; ibrahim, s. A. M.(2011). Using mixture of sweet basal and black cumin as feed additives with different levels of energy in growing rabbit diets. American-eurasian journal of agricultural \& environmental sciences; 2011. 10(5):917-927. 38 ref.

- Ali, m.n., m.s. Hassan and f.a. Abd el-ghany, (2007). Effect of strain, type of natural antioxidant and sulphate ion on productive, physiological and hatching performance of native laying hens. Int. J poult. Sci., 6: 539-554.

- B r e n e s a., r o u r a e. (2010). Essential oils in poultry nutrition: main effects and modes of action. Anim. Feed sci. Tech., 158: 1-14.

- Bonsu, r. K.; kagya-agyemang, j. K.; kwenin, w. K. J.; zanu, h. K.(2012). Medicinal response of broiler chickens to diets containing neem (azadirachta indica) leaf meal, haematology and meat sensory analysis. World applied sciences journal; 2012. 19(6):800-805. 12 ref.

- C e r i s u e l o a., m a rín c., sá n c h e z-viz caín of., gó m e z e.a., d e la fu e nt e j.m., d u r á n r., f e r $\mathbf{n}$ á $\mathbf{n} \mathbf{d}$ e $z$ c. (2014). The impact of a specific blend of essential oil components and sodium butyrate in feed on growth performance and salmonella counts in experimentally challenged broilers. Poultry sci., 3: 599-606.

- Case, g.l., l. He, h. Mo and c.e. Elson, (1995). Induction of geranyl pyrophosphatase activity by cholesterol - suppressive isoprenoids. Lipids, 30: 357-359.

- Channa, a. A.; qazi, i. H.; soomro, s. A.; shah, a. H.; gandahi, j. A.; korejo, r. A.; shah, i. A.; kalhoro, n. A.; band-e-ali khaskeli.(2014). Effect of oral supplementation of aloe vera extract on haematology indices and immune cells of blood in rabbit. African journal of pharmacy and pharmacology; 2014. 8(19):497-501. 20 ref.

- Cheek p. R., m. N. Patton and g.s. Tempelton (1982). Rabbit production. The interstate printers and publishers, danville iii.p.125.

- Cowan, m.m., (1999). Plant products as antimicrobial agents. Clin. Microbiol. Rev. 12, 564-582.

- D e m i r e., k i l i n c k., y i l d i r i m y., d i n c e r f., e s e c e l h. (2008). Comparative effects of mint, sage, thyme and flavomycin in wheat-based broiler diets. Arch. Zootec., 11: 54-63.

- D e o livi e r a t.l., s o ar e s r., r a mo s e.m., c a r d o s o m., a l v e s e., p i c c o 1 i r.h. (2011).

- Duncan, d.b. (1955).multiple range and multiple f test. Biometrics, 1-24. 
- Elsherbiny a. Elsherbiny, basma h. Amin, zakaria a. Baka.(2015). Efficiency of pomegranate(punica granatum 1.) Peels extract as a high potential natural tool towards fusarium dry rot on potato tubers . Postharvest biology and technology 111(2016)256 263.

- Eslami, m.; baghaei, m.; mamouei, m.; chaji, m.; ashayerizadeh, a.(2010). Effects of avilamycin, formycingold and fyto-mix on serum lipid concentrations of young broilers. Journal of animal and veterinary advances; 2010. 9(1):108-111. 30 ref.

- Ferket p. Strategies for finding alternatives to growth promoters, (2011). Available from: $\quad \mathrm{http} / /$ en.engormix.com/ma-poultry-industry/management/articles/strategiesfinding-alternatives-growth-t1771/ 124-p0.htm. Accessed august 1, 2012.

- Feynman r. Lecture at the california institute of technology; 1959. December 29.

- Fondevila, m., rubio, s., de vega, a.,moreno, c., (2001). Efecto de la inclusion de diferentes combinaciones de Jcidos org Jnicos en dietas para cerdos en transicion sobre sus rendimientos productivos y distintos parJmetros digestivos. Itea 22 (suppl. 1), 298300 .

- Fondevila, m., rubio, s., de vega, a.,moreno, c., (2001). Efecto de la inclusion de diferentes combinaciones de Jcidos org Jnicos en dietas para cerdos en transicinn sobre sus rendimientos productivos y distintos parJmetros digestivos. Itea 22 (suppl. 1), 298300.

- Franco, l.d., fondevila, m., lobera, m., castrillo, c., (2005). Effect of combinations of organic acids inweaned pig diets on microbial species of digestive tract contents and their response on digestibility. J. Anim. Physiol. Anim. Nutr. 89, 88-93.

- Gardiner, g.e., casey, p.g., casey, g., lynch, p.b., lawlor, p.g., hill, c., fitzgerald, g.f., stanton, c., ross, r.p., (2004). Relative ability of orally administered lactobacillus murinus to predominate and persist in the porcine gastrointestinal tract. Appl. Environ. Microbiol. 70, 1895-1906.

- Gong p, li h, he $\mathbf{x}$, wang $\mathbf{k}$, hu j, tan w, et al(2007). Preparation and antibacterial activity of fe3o4@ag nanoparticles. Nanotechnology 2007;18:604-11.

- Gu h, ho pl, tong e,wang l, xu b(2003). Presenting vancomycin on nanoparticles to enhance antimicrobial activities. Nano lett 2003;3(9):1261-3.

- H o n g j.c., s t e i n e r t., a u f y a., l i e n t.f. (2012). Effects of supplemental essential oil on growth performance, lipid metabolites and immunity, intestinal characteristics, microbiota and carcass traits in broilers. Livest sci., 144: 253-262.

- Hajati, h.; hasanabadi, a.; waldroup, p. W. (2011). Effects of dietary supplementation with pumpkin oil (cucurbita pepo) on performance and blood fat of broiler chickens during finisher period. American journal of animal and veterinary sciences; 2011. 6(1):40-44. 24 ref.

- Ibrahim, sh. A. M. (2005). Effect of some medicinal plants as feed additives on growth and some metabolic changes in rabbits. Egypt. J. Nutr. And feeds., 8 (2) : 207-219.

- Ismail, f.s.a (2004). Wheat screening by product in growing rabbits diets. Egyptian. J. Of rabbit sci., 14(1): 65-79.

- Jang ( 2015). Effects of by-products of herbal medicine on performance, intestinal microbial population, blood biochemical profiles and immunological parameters in broiler chicks. [korean]. Korean journal of poultry science; 2015. 42(4):307-314. 30 ref.

- K h a t t a k f., r o n c h i a., c a s t e l l i p., s p a r k s n. (2014). Effects of natural blend of essential oil on growth performance, blood biochemistry, cecal morphology, and carcass quality of broiler chickens. Poultry sci., 1: 132-137. 
- K i r k p i n a r f., u n u 1 u h.b., o z d e m i r g. (2011). Effects of oregano and garlic essential oils on performance, carcase, organ and blood characteristics and intestinal microfora of broilers. Livestock sci., 137: 219-225.

- Kermanshahi, h. And a. Riasi,( 2006). Effect of turmeric rhizome powder (curcuma longa) and soluble nsp degrading enzyme on some blood parameters of laying hens. Int. J. Poult. Sci., 5: 494-498.

- Kim js, kuk e, yu kn, kim jh, park sj, lee hj, et al(2007). Antimicrobial effects of silver nanoparticles. Nanomed nanotechnol biol med 2007;3:95-101.

- Lee hj, yeo sy, jeong sh. 2003. Antibacterial effect of nanosized silver colloidal solution on textile fabrics. J mater sci 38: 2199_2204.

- M a t h l o u t h i n., o u e s l a t i i., r e coqu i l l a y f., h a m d i m., u r d a c i m., b e r g a o u o r. (2012). Use of rosemary, oregano, and a commercial blend of essential oils in broiler chickens: in vitro antimicrobial activities and effects on growth performance. J. Anim. Sci., 90: 813-823.

- Mo u n t z u ris k.c., p a r a s e v s v., t s i rtsi k o s p., p a l a midi i., st e i n e $\mathbf{r}$ t.,

- Morones jr, elechiguerra jl, camacho a, ramirez jt(2005). The bactericidal effect of silver nanoparticles. Nanotechnology 2005;16:2346-53.

- N a z z a rof., f r a t i a n $n$ i f., d e martion ol., c op pol a l., d e f e o v. (2013). Effect of essentials oils on pathogenic bacteria. Pharmaceutic., 6: 1451-1474.

- N i m b a r t e s., k u l k a r n i a. (2013). Comparative phytochemical analysis and resilience pattern exhibited by thyme and tea tree oil against selected poultry isolates. J. Agri. Vet. Sci., 4: 113-117.

- Naughton, P.J., Mikkelsen, L.L., Jensen, B.B., (2001). Effects of nondigestible oligosaccharides on Salmonella enterica serovar Typhimurium and nonpathogenic Escherichia coli in the pig small intestine in vitro. Appl. Environ. Microbiol. 67, 33913395.

- Ognik, K.; Sembratowicz, I.; Cholewinska, E.; Wlazlo, L.; Nowakowicz-Debek, B.; Szlazak, R.; Tutaj, K.(2016). The effect of chemically-synthesized silver nanoparticles on performance and the histology and microbiological profile of the jejunum in chickens. Annals of Animal Science; 2016. 16(2):439-450. 26 ref.

- Oleforuh-Okoleh, V. U.; Olorunleke, S. O.; Nte, I. J.(2015). Comparative response of bitter leaf (Vernonia amygdalina) infusion administration on performance, haematology and serum biochemistry of broiler chicks. Asian Journal of Animal Sciences; 2015. 9(5):217-224. 32 ref.

- Percival, S.L., Bowler, P.G., Russell, D., (2005). Bacterial resistance to silver in wound care. J. Hosp. Infect. 60, 1-7.

- Pineda, L.; Chwalibog, A.; Sawosz, E.; Lauridsen, C.; Engberg, R.; Elnif, J.; Hotowy, A.; Sawosz, F.; Gao YuHong; Ali, A.; Moghaddam, H. S.(2012). Effect of silver nanoparticles on growth performance, metabolism and microbial profile of broiler chickens. Archives of Animal Nutrition; 2012. 66(5):416-429. 34 ref.

- Pluske, J.R.,Hampson, D.J., Williams, I.A., (1997). Factors influencing the structure and function of the small intestine in theweaned pig: a review. Livest. Prod. Sci. 51, 215236.

- Puvaca, N. M.; Kostadinovic, L. M.; uragic, O. M.; Ljubojevic, D. B.; Miscevic, B. M.; Konyves, T. L.; Popovic, S. J.; Levic, J. D.; Nikolova, N. B.(2016). Influence of herbal drugs in broiler chicken nutrition on primal carcass cuts quality assessments. Food and Feed Research; 2016. 43(1):43-50. 26 ref. 
- $\quad$ R o o f c h a e e A., M e h r a d a d I., E b r a h i m z a d e e h M.A., A k b a r i M.R. (2011). Effect of dietary oregano (Origanum vulgare L.) essential oil on growth performance, cecal microflora and serum antioxidant activity of broiler chickens. Afr. J. Biotech., 32: 6177-6183.

- Radwan Nadia L., (2003). Effect of using some medicinal plants on performance and immunity of broiler chicks. Ph.D. Thesis, Poult. Nutr. Dept. Fac. Agric. Cairo University.

- Retchkiman-Schabes PS, Canizal G, Becerra-Herrera R, Zorrilla C, Liu HB, Ascencio JA(2009). Biosynthesis and characterization of Ti/Ni bimetallic nanoparticles. Opt. Mater. 2006;29:95-9.

- Riyazi, S. R.; Ebrahimnezhad, Y.; Hosseini, S. A.; Meimandipour, A.; Ghorbani, A(2015). Comparison of the effects of basil (Ocimum basilicum) essential oil, avilamycin and protexin on broiler performance, blood biochemistry and carcass characteristics. Archives Animal Breeding; 2015. 58(2):425-432. 41 ref.

- S a l e h N., A I l a m T., E 1 - I a $t$ i f A.A., G h a z y E. (2014). The effects of dietary supplementation of different levels of thyme (Thymus vulgaris) and ginger (Zingiber officinale) essential oils on performance, hematological, biochemical and immunological parameters of broiler chickens. Global Vet., 6: 736-744.

- S c h a t z m a y r G., F e g e r o s K. (2011). Assessment of a phytogenic feed additive effect on broiler growth performance, nutrient effect of phytogenic additives on performance, morphology, digestibility and cecal microflora composition. Anim. Feed Sci. Tech., 168: 223-231.

- Sharifi, S. D.; Khorsandi, S. H.; Khadem, A.; Salehi, A.(2012). The effect of four medicinal plants on performance and concentration of serum lipids in broiler chicks. [Persian] Journal of Medicinal Plants; 2012. 11(Supplement 8):Pe83-Pe92, En7. 26 ref .

- Sharma, R. K.; Maini, S.; Ravikanth, K.(2009). Beneficial effects of Superliv DS and Xlivpro on growth promotion and carcass quality traits in broilers. Veterinary World; 2008. 1(12):363-365. 10 ref.

- Sondi I, Salopek-Sondi B.( 2004). Silver nanoparticles as antimicrobial agent: A case study on E. coli as a model for Gramnegative bacteria. J Colloid Interface Sci 275:177_182.

- Tabari, M. A.; Ghazvinian, Kh.; Irani, M.; Molaei, R.(2016). Effects of dietary supplementation of nettle root extract and pumpkin seed oil on production traits and intestinal microflora in broiler chickens. Bulgarian Journal of Veterinary Medicine; 2016. 19(2):108-116. 25 ref.

- Taniguchi N. On the Basic Concept of Nano-Technology. Proc. Intl. Conf. Prod. Eng. Tokyo, Part II. Japan Society of Precision Engineering; 1974.

- Waskar, V. S.; Gosavi, P. P.; Devangare, A. A.; Kanduri, A. B.; Maini, S.; Ravikanth, K.(2011). Meat attributes of chicken broilers raised on coccihar - a polyherbal coccidiostat feed additive. Animal Science Reporter; 2011. 5(1):16-21. 21 ref.

- Wright, J.B., Lam, K., Burrell, R.E., (1994). Wound management in an era of increasing bacterial antibiotic resistance: a role for topical silver treatment. Am. J. Inf. Control 26, 572-577.

- Z e n g Z., Z h a n g S., Wa n g H., P a i o X. (2015). Essential oil and aromatic plants as feed additives in non-ruminant nutrition: a review. J. Anim. Sci. Biotechnol., 6: 7-15. 